\title{
Pozyskanie tajnego współpracownika przez służby kontrwywiadowcze na podstawie materiałów obciążających - rozważania o sensie instytucji
}

\author{
Piotr HeRbowski \\ ORCID: 0000-0002-7736-3614 \\ Katedra Prawa Karnego
}

SWPS Uniwersytetu Humanistycznospołecznego, Wydział Zamiejscowy w Poznaniu

\section{Uwagi wstępne}

Jednym z podstawowych zadań, jakie stoją przed władzą państwową, jest z pewnością zapewnienie bezpieczeństwa strukturom państwa oraz obywatelom przed zachowaniami godzącymi w cenne społecznie dobra prawne. Przejawia się to w podejmowaniu czynności, które prowadzą do wyeliminowania takich zagrożeń ${ }^{1}$. Trybunał Konstytucyjny wskazał w jednym ze swoich orzeczeń, że oznacza to nie tylko skuteczne ściganie dokonanych już naruszeń prawa, lecz także konieczność przeciwdziałania takim zagrożeniom ${ }^{2}$. Są to więc działania uzasadnione nadrzędnym interesem publicznym, jakim jest z pewnością zapewnienie bezpieczeństwa państwa, a więc także porządku publicznego oraz ochrona życia,

1 I. Nowikowski, Bezpieczeństwo państwa a prawa oskarżonego w polskim prawie karnym procesowym (kwestie wybrane), Teka Komisji Prawniczej O.L. PAN, 11, 2018, nr 2, s. 294.

2 Uzasadnienie wyroku TK z 23 czerwca 2009 r., w sprawie K 54/07, OTK ZU 2009, nr 6A, poz. 86 . 
zdrowia i mienia obywateli. Konieczność taką można wywieść z treści art. 5 Konstytucji RP, w którym wskazano, że Rzeczpospolita Polska strzeże niepodległości i nienaruszalności swego terytorium, zapewnia wolności i prawa człowieka i obywatela oraz bezpieczeństwo obywateli, strzeże dziedzictwa narodowego oraz zapewnia ochronę środowiska, kierując się zasadą zrównoważonego rozwoju. Wprowadzając instytucje prawne służące wymienionym celom, a więc na przykład umożliwiające służbom specjalnym przeciwdziałanie i walkę z zagrożeniami terrorystycznymi oraz szpiegowskimi, należy kierować się trafną obserwacją A. Tarachy, iż:

dotykamy tu niezwykle delikatnej materii. $\mathrm{Z}$ jednej strony zbyt szerokie uprawnienia służb specjalnych i policyjnych do prowadzenia tajnych operacji zagrażają prawom i wolnościom obywatelskim, co może rodzić uzasadnione obawy o przekształcenie się państwa prawa w państwo policyjne. $Z$ drugiej zaś zbytnie krępowanie organów odpowiedzialnych za bezpieczeństwo publiczne (w imię ochrony praw jednostki) może spowodować, że nie będą one w stanie realizować skutecznie swoich obowiązków. Rozsądne wyważenie proporcji jest tu z pewnością zadaniem trudnym, ale koniecznym ${ }^{3}$.

\section{Podstawy prawne i nazewnictwo}

Przez wiele lat przyjętą w Polsce praktyką w zakresie uregulowań umożliwiających zwalczanie terroryzmu było dostosowywanie istniejących przepisów ustawowych do standardów międzynarodowych. Odpowiednie regulacje były również wprowadzane do ustaw kompetencyjnych służb specjalnych i policyjnych. Taki model legislacyjny powodował, że problematyka dotycząca rozpoznawania i zwalczania terroryzmu była bardzo rozproszona ${ }^{4}$. Istotną zmianą było uchwalenie ustawy z dnia 10 czerwca 2016 roku o działaniach antyterrorystycznych ${ }^{5}$, która zawiera skonsoli-

${ }^{3}$ A. Taracha, Glosa do wyroku Trybunatu Konstytucyjnego z dnia 20 kwietnia $2004 \mathrm{r}$. (sygn. akt K 45/02), „Przegląd Sejmowy” 2004, nr 6, s. 200.

${ }^{4}$ A. Babiński, Ustawa antyterrorystyczna - legislacja na rzecz bezpieczeństwa, [w:] Polska ustawa antyterrorystyczna: odpowiedź na zagrożenia wspótczesnym terroryzmem, red. W. Zubrzycki, K. Jałoszyński, A. Babiński, Szczytno 2016, s. 236-238.

5 Dz.U. z 2018 r. poz. 452, 650, 730.

Nowa Kodyfikacja Prawa Karnego 51, 2019

(C) for this edition by CNS 
dowane normy w zakresie przeciwdziałania terroryzmowi ${ }^{6}$. Uregulowanie $\mathrm{w}$ jednym akcie ustawowym zagadnień związanych z zapobieganiem i zwalczaniem zagrożeń terrorystycznych jest właściwym rozwiązaniem. Jednak już przed przyjęciem tej ustawy pojawiły się głosy wskazujące na ewentualne naruszenia konstytucyjnie gwarantowanych praw i wolności, mogące wiązać się ze zbytnim poszerzeniem uprawnień służb specjalnych i policyjnych do ingerencji w prawa człowieka ${ }^{7}$.

Niektóre rozwiązania zawarte w tej ustawie już stały się przedmiotem rozważań w piśmiennictwie ${ }^{8}$. Natomiast instytucji dopuszczającej możliwość pozyskania przez służby kontrwywiadowcze tajnych współpracowników na podstawie posiadanych materiałów obciążających ${ }^{9}$, która w istocie jest nowym kontratypem pozaustawowym ${ }^{10}$, nie poświęcono dotąd szczególnej uwagi. Ze znacznie większym zainteresowaniem spotykają się od lat te działania służb państwowych, które uznawane są za bardziej ingerujące w prawa człowieka, a więc wkraczające w prawa i wolności konstytucyjne. Zalicza się do nich przede wszystkim kontrolę operacyjną oraz ofensywne formy pracy operacyjnej określane niekiedy

${ }^{6}$ W. Zubrzycki, Dzieje ustawy antyterrorystycznej w Polsce, [w:] Polska ustawa antyterrorystyczna..., s. 259.

7 Zob. m.in. Wniosek Rzecznika Praw Obywatelskich z dnia 18 lutego 2016 r. o stwierdzenie niezgodności z Konstytucją Rzeczypospolitej niektórych przepisów ustawy o Policji oraz niektórych innych ustaw (znowelizowanych ustawą z 15 stycznia 2016 r. Dz.U. z 2016 r., poz. 147); M. Szuniewicz-Stępień, Działania operacyjno-rozpoznawcze w ustawie antyterrorystycznej a europejski standard ochrony praw czlowieka - wybrane zagadnienia, [w:] Polska ustawa antyterrorystyczna..., s. 335-368.

${ }^{8}$ Zob. m.in. P. Lubiewski, Ustawa antyterrorystyczna wobec stużb specjalnych. Rozszerzenie czy aktualizacja, [w:] Polska ustawa antyterrorystyczna..., s. 303-321; W. Olsztyn, Nowe rozwiazania $w$ obszarze działan operacyjno-rozpoznawczych oraz procesowych wynikajace z ustawy o działaniach antyterrorystycznych, [w:] Polska ustawa antyterrorystyczna..., s. 323-334; oraz M. Wosek, Działania antyterrorystyczne w aspekcie praw człowieka i wolności obywatelskich, [w:] Polska ustawa antyterrorystyczna..., s. 583-590.

9 A. Taracha, Nowe regulacje dotyczace czynności operacyjno-rozpoznawczych zawarte w Ustawie z dnia 10 czerwca 2016 r. o dziataniach antyterrorystycznych, [w:] Pozyskiwanie informacji w walce z terroryzmem, red. P. Herbowski, D. Słapczyńska, D. Jagiełł, Warszawa 2017, s. 11.

10 S. Hoc, O tak zwanym szpiegu i terroryście koronnym, „Nowa Kodyfikacja Prawa Karnego" 43, 2017, s. 174.

Nowa Kodyfikacja Prawa Karnego 51, 2019

(C) for this edition by CNS 
zbiorczo mianem prowokacji policyjnej (zakup kontrolowany oraz kontrolowane przyjęcie lub wręczenie korzyści majątkowej) ${ }^{11}$.

Instytucja ta jest $\mathrm{w}$ pewnej mierze wzorowana na rozwiązaniach zawartych $\mathrm{w}$ ustawie o świadku koronnym ${ }^{12}$. Przede wszystkim wiąże się to $\mathrm{z}$ odejściem od zasady legalizmu na rzecz zasady oportunizmu, co znalazło swoje odzwierciedlenie w sformułowaniu zawartym $\mathrm{w} z$ art. $22 \mathrm{~b}$ ust. 1 pkt 2 ustawy o Agencji Bezpieczeństwa Wewnętrznego i Agencji Wywiadu $^{13}$ oraz art. 27a ust. 1 pkt 2 ustawy o Służbie Kontrwywiadu Wojskowego i Służbie Wywiadu Wojskowego ${ }^{14}$, iż szefowie ABW lub SKW mogą w przypadkach, gdy jest to uzasadnione względami bezpieczeństwa państwa, odstąpić od obowiązku zawiadomienia właściwego prokuratora o uzasadnionym podejrzeniu popełnienia przestępstwa.

Analizowany instrument prawny S. Hoc określił mianem tak zwanego szpiega lub terrorysty koronnego ${ }^{15}$. Wydaje się jednak, że ta nazwa, aczkolwiek oddająca w pewnej mierze jego sens, nie w pełni odzwierciedla intencje ustawodawcy, które da się wprost odczytać z art. $22 \mathrm{~b}$ ust. 2 pkt 2 ustawy o ABW i AW oraz art. 27a ust. 2 pkt 2 ustawy o SKW i SWW. Mówi się w nich o podjęciu tajnej współpracy z ABW lub SKW, wobec tego zasadnym byłoby raczej przyjęcie, że mamy do czynienia z tajnym współpracownikiem służb kontrwywiadowczych pozyskanym z wykorzystaniem materiałów obciążających (dalej: TW). Należy przy tym zaznaczyć, iż nazwa ta nie jest w żadnej mierze odpowiednikiem jednej z najważniejszych kategorii osobowych źródeł informacji, funkcjonującej w służbach milicyjnych i specjalnych w okresie PRL-u ${ }^{16}$.

11 A. Taracha, Uzyskiwanie i wykorzystywanie dla celów bezpieczeństwa informacji o osobie a prawa jednostki (zagadnienia wybrane), Teka Komisji Prawniczej O.L. PAN, 11, 2018, nr 2, s. 445.

12 A. Taracha, Nowe regulacje..., s. 11.

13 Dz.U. z 2002 r. Nr 74, poz. 676 z późn. zm.

14 Dz.U. z 2006 r. Nr 104, poz. 709 z późn. zm.

15 S. Hoc, op. cit., s. 153.

16 Zob. szerzej F. Musiał, Podręcznik bezpieki. Teoria pracy operacyjnej Stużby Bezpieczeństwa w świetle wydawnictw resortowych Ministerstwa Spraw Wewnętrznych PRL (1970-1989), Kraków 2007, s. 89-155. 


\section{Geneza instytucji}

Od chwili zakończenia tak zwanej zimnej wojny w działaniach operacyjnych podejmowanych przez służby specjalne wielu państw, w tym przede wszystkim Stanów Zjednoczonych, widoczna była istotna przewaga wywiadu elektronicznego nad wywiadem agenturalnym. W praktyce oznaczało to marginalizację wywiadu i kontrwywiadu osobowego ${ }^{17}$ i prowadziło do nadmiernego polegania na możliwościach, jakie dawały środki techniczne. Przykładem może być brak źródeł osobowych odpowiednio uplasowanych w Al-Kaidzie, której system komunikacji oparto w głównej mierze na kurierach, co ułatwiło przygotowanie i realizację zamachów z 11 września 2001 roku $^{18}$. Dowodzi to, że takie podejście było błędne. Jednocześnie trzeba podkreślić, że $\mathrm{w}$ wielu wypadkach wiedza pochodząca ze źródeł osobowych, mimo że skromna ilościowo wobec danych uzyskiwanych za pomocą środków technicznych, miała kluczowe znaczenie dla prowadzonych działań. $\mathrm{W}$ ostatnich latach ponownie wskazuje się więc na wywiad agenturalny jako najbardziej efektywny rodzaj rozpoznania $\mathrm{w}$ przypadku walki z terroryzmem ${ }^{19}$, ale także z działalnością szpiegowską. Wobec tego nie sposób podważyć twierdzenia o kluczowej roli, jaką odgrywają poufne osobowe źródła informacji (dalej: POZI ${ }^{20}$. Poglądy o możliwości zastąpienia ich środkami technicznymi, określane niekiedy mianem ,śledztwa telekomunikacyjnego" ${ }^{21}$, nie znajdują żadnego potwierdzenia w praktyce działań operacyjnych służb spe-

17 G. Kostrzewa-Zorbas, Zachwycone technologia i prawem, stużby specjalne USA nie rozumieja ludzi $i$ kultur. Błąd stary, ale żywy $i$ zaraźliwy, http://wpolityce.pl/swiat/296394-zachwycone-technologia-i-prawem-sluzby-specjalne-usa-nie-rozumieja-ludzii-kultur-blad-stary-ale-zywy-i-zarazliwy (dostęp: 17.05.2019).

18 Zob. także raport specjalnej Komisji Kongresu Stanów Zjednoczonych The 9/11 Commission Report, https://www.9-11commission.gov/report/911Report.pdf (dostęp: 17.05.2019).

19 R. Jagiełł, Wybrane aspekty wojskowego rozpoznania osobowego, „Przegląd Bezpieczeństwa Wewnętrznego" 2013, nr 5, s. 236.

20 Pod tym pojęciem należy rozumieć wszystkie kategorie osób, które niejawnie przekazują informacje służbom policyjnym i specjalnym. Szerzej P. Herbowski, Poufne osobowe źródta informacji. Aspekty kryminalistyczne i prawnodowodowe, Warszawa 2018, s. 9, 166-193.

21 A. Staszak, Porwania w celu wymuszenia okupu. Studium kryminalistyczne, Opole 2010 , s. 276.

Nowa Kodyfikacja Prawa Karnego 51, 2019

(C) for this edition by CNS 
cjalnych. Największy potencjał w zakresie działań proaktywnych, które racjonalizują wysiłki tych służb i zwiększają ich skuteczność, a więc będą rozwijały się w coraz szybszym tempie ${ }^{22}$, można dostrzec w efektywnej współpracy z POZI. W piśmiennictwie od wielu lat słusznie wskazuje się właśnie na tę formę pracy operacyjnej jako towarzyszącą wszelkim podejmowanym w tym obszarze działaniom. Trafnie przyznaje się jej rolę konstytuującą określeniu istoty niejawnych działań podejmowanych przez organy państwowe realizujące swoje działania w sferze bezpieczeństwa publicznego $^{23}$. Należało więc wyciągnąć konstruktywne wnioski z błędów popełnianych od wielu lat przez służby specjalne różnych państw i stworzyć również w Polsce odpowiednie podstawy prawne skuteczniejszego pozyskiwania informacji o zagrożeniach terrorystycznych. Konieczne jest przy tym także wzięcie pod uwagę tych związanych z działalnością szpiegowską służb specjalnych państw kwestionujących obecny ład polityczny w Europie Środkowo-Wschodniej.

Przyjmując, że kluczową rolę w pozyskiwaniu informacji o działalności szpiegowskiej zagrażającej naszemu bezpieczeństwu narodowemu i dobrobytowi gospodarczemu kraju, jak i tej podejmowanej przez grupy terrorystyczne odgrywają źródła osobowe, trzeba rozważyć, która z form infiltracji — bezpośrednia czy też pośrednia — może być skuteczniejsza. Wydaje się, że ograniczoną przydatność w polskim porządku prawnym miała dotąd infiltracja pośrednia, czyli współpraca z POZI. Związane było to z problemami z werbunkiem źródła, czyli znalezieniem odpowiedniej podstawy pozyskania oraz kwestią zaufania, jakim można je obdarzyć. Istotne znaczenie miała także lakoniczność obowiązujących przepisów prawnych, będących w istocie jedynie pewnym rozwinięciem treści art. 15 ustawy z dnia 14 lipca 1983 roku o urzędzie Ministra Spraw Wewnętrznych i zakresie działania podległych mu organów ${ }^{24}$.

Za bardziej efektywną, co oczywiście nie znaczy, że łatwiejszą w prowadzeniu, mogła być uznawana infiltracja bezpośrednia, realizowana z udzia-

22 J. Konieczny, Kryzys czy zmiana paradygmatu kryminalistyki?, „Państwo i Prawo" 2012, z. 1, s. 6.

23 S. Zalewski, Czynności operacyjno-rozpoznawcze jako forma realizacji zadań stużb specjalnych $w$ systemie bezpieczeństwa państwa, „Przegląd Policyjny” 2002, nr 3-4, s. 132.

24 Dz.U. z 1983 r. Nr 38, poz. 172. Ustawa została uchylona 10 maja 1990 roku.

Nowa Kodyfikacja Prawa Karnego 51, 2019

(C) for this edition by CNS 
łem funkcjonariuszy działających „pod przykryciem” (dalej: FPP), czyli kadrowych funkcjonariuszy służb ${ }^{25}$. Stosowano ją od wielu lat w czynnościach operacyjnych ukierunkowanych na zwalczanie zorganizowanych grup przestępczych. W okresie PRL-u prowadzono ją jednak bez jakiegokolwiek umocowania ustawowego. Dopiero w roku 1995 znowelizowano tak zwane ustawy policyjne, dające wreszcie podstawy prawne do działań tak zwanych przykrywkowców ${ }^{26}$. Głównym celem tego rodzaju infiltracji powinno być sygnalizowanie o możliwości zaistnienia zagrożeń terrorystycznych ${ }^{27}$. Jednak z uwagi na konieczność inwigilacji grup, które charakteryzują się najczęściej znaczną hermetycznością, przydatność tej formy pracy operacyjnej będzie raczej niewielka.

W sytuacji realnego wzrostu zagrożenia bezpieczeństwa państwowego i publicznego, a co się z tym bezpośrednio wiąże — zagrożeń dla życia i zdrowia obywateli, każde państwo ma prawo stosować środki adekwatne do zaistniałego niebezpieczeństwa. Takim środkiem nie będą z pewnością działania FPP w ich obecnej postaci. Instrumentem prawnym, który w obliczu zagrożeń terrorystycznych i szpiegowskich ma szanse na uzyskanie społecznej akceptacji, jest z pewnością możliwość pozyskania przez służby kontrwywiadowcze TW na podstawie materiałów obciążających. Nie ulega wątpliwości, że działania prowadzone za pośrednictwem źródeł osobowych opierają się w głównej mierze na podstępie ${ }^{28}$, który polega na świadomym wprowadzaniu w błąd innych osób co do ich faktycznej tożsamości i zamiarów. W odniesieniu do tej formy pracy operacyjnej uzasadnione jest stanowisko, iż jest ona środkiem prowadzącym do osiągnięcia zakładanych celów w warunkach tak zwanej kooperacji negatywnej, realizowanej zgodnie z zasadami orga-

25 J. Mąka, Ustawa o czynnościach operacyjno-rozpoznawczych - czy jest potrzebna w obecnym stanie prawnym w Polsce?, „Prokuratura i Prawo” 2009, nr 4, s. 139, przypis 25.

26 A. Taracha, Z problematyki sporzadzania $i$ wydawania operacyjnych dokumentów legalizacyjnych, [w:] Dokument i jego badania, red. R. Cieśla, Wrocław 2014, s. 371-372.

27 K. Olejnik, Zakres stosowania czynności operacyjnych - stan faktyczny, oczekiwania, potrzeby i możliwości wykorzystania ustaleń operacyjnych $w$ procesie karnym oraz dopuszczalny udziat sędziego i prokuratora $w$ działaniach operacyjnych, [w:] Praktyczne elementy zwalczania przesteppzości zorganizowanej i terroryzmu. Nowoczesne technologie i praca operacyjna, red. L. Paprzycki, Z. Rau, Warszawa 2009, s. 641.

28 Zob. m.in. B. Kurzępa, Podstęp w toku czynności karnoprocesowych i operacyjnych, Toruń 2003, s. 159.

Nowa Kodyfikacja Prawa Karnego 51, 2019

(C) for this edition by CNS 
nizacji walki ${ }^{29}$. Już sam fakt realizacji takich działań może wywoływać nie tylko wśród prawników liczne wątpliwości, dotyczące etyczności ich stosowania. Trzeba jednak wziąć pod uwagę trafny pogląd M. Kulickiego, którego zdaniem

Walka nierzetelna, w której arogancko stosuje się metody nieetyczne i bezprawne (presję fizyczną, poniżanie godności osobistej, szantaż, udręczenie psychiczne, podżeganie do relacjonowania narzuconych treści, wprowadzanie w błąd co do przysługujących uprawnień), jest, w zestawieniu z zasadami kryminalistycznej taktyki walki, alternatywą nieporównanie gorszą ${ }^{30}$.

\section{Rozwiązania szczegółowe}

Rozważając zasadność funkcjonowania w polskim porządku prawnym instytucji TW, konieczne jest także przeanalizowanie poszczególnych rozwiązań będących jej elementami składowymi. W stosunku do niektórych z nich można bowiem sformułować wiele zastrzeżeń, a jednocześnie zaproponować takie rozwiązania, które mogą być nie tylko efektywne, lecz także zgodne z polskim porządkiem prawnym. W szczególności dotyczy to faktycznego przywileju niekaralności, którym obdarza się TW i kontroli instytucji wymiaru sprawiedliwości w odniesieniu do zasadności zastosowania tego instrumentu prawnego.

W historii polskiego prawodawstwa pierwszą próbą kompleksowego uregulowania zagadnień niejawnego pozyskiwania informacji były prace nad projektem ustawy o czynnościach operacyjno-rozpoznawczych ${ }^{31}$ (dalej: u.o.c.o.r). Większość problemów, z którymi próbowano się zmierzyć, można w dużej mierze zakwalifikować jako bezpośrednio lub pośrednio związane ze współpracą ze źródłami osobowymi. W dużym stopniu znalazło to odzwierciedlenie $\mathrm{w}$ tak zwanym projekcie eksperckim

29 Zob. szerzej J. Rudniański, Elementy prakseologicznej teorii walki. Z zagadnień kooperacji negatywnej, Warszawa 1983, s. 27-37.

30 M. Kulicki, V. Kwiatkowska-Darul, L. Stępka, Kryminalistyka. Wybrane zagadnienia teorii i praktyki śledczo-sąowej, Torun 2005, s. 50.

31 R. Netczuk, Tajny wspótpracownik i tajny agent $w$ projektach ustaw o czynnościach o czynnościach operacyjno-rozpoznawczych: uwagi de lege ferenda, „Wojskowy Przegląd Prawniczy" 2010, nr 3, s. 11. 
u.o.c.o.r ${ }^{32}$, który przygotowano w ramach powołanego przez Ministra Spraw Wewnętrznych i Administracji zespołu, a następnie przekazano do sejmowej komisji administracji i spraw wewnętrznych, by stanowił uzupełnienie projektu poselskiego ${ }^{33}$. Niestety podczas tych prac wspomniane problemy nie były przedmiotem szerszej dyskusji w środowiskach prawniczych, lecz przede wszystkim w trakcie zamkniętych paneli operacyjnych i dyskusji eksperckich. Nie pozwoliło to na spojrzenie na tę problematykę z innej perspektywy i bezpośrednio przełożyło się na jakość przygotowanych rozwiązań. Podstawowe wątpliwości wywołuje przede wszystkim zagadnienie niejawnej współpracy osób z funkcjonariuszami służb państwowych, gdyż nie zawarto wyczerpującej definicji takiej współpracy, a co więcej, nie jest ona wyrażona wprost ${ }^{34}$. Brakuje też precyzyjnych definicji nawet podstawowych instytucji, które próbowano uregulować w projekcie eksperckim u.o.c.o.r, co w opinii T. Tomaszewskiego było jego istotną wadą. Takie działania określił on wręcz mianem uników definicyjnych ${ }^{35}$.

W trakcie prac nad ustawą z 10 czerwca 2016 roku o działaniach antyterrorystycznych punktem wyjścia w odniesieniu do instytucji TW były niewątpliwie propozycje przepisów zawarte w tak zwanym projekcie eksperckim u.o.c.o.r, a w szczególności jego art. $12^{36}$.

Art. 12.1. Jeżeli w trakcie realizacji przez służby państwowe ich ustawowych zadań uzyskane zostaną informacje lub materiały wskazujące na uzasadnione podejrzenie po-

32 Zob. Z. Rau, Czynności operacyjno-rozpoznawcze w polskim systemie prawa — działania w kierunku uniwersalnej ustawy, [w:] Praktyczne elementy zwalczania..., s. $732-744$.

33 Zob. Stanowisko Rady Ministrów wobec poselskiego projektu ustawy o czynnościach operacyjno-rozpoznawczych (druk nr 353) z dnia 30 czerwca 2008 r., http://orka. sejm.gov.pl/Druki6ka.nsf/0/99F9EEEE5BE058A6C1257481003704AA/\$file/353-s.pdf (dostęp: 2.06.2019).

34 A. Taracha, $O$ „Projekcie ustawy o czynnościach operacyjno-rozpoznawczych”, „Annales Universitatis Mariae Curie-Skłodowska. Sectio G” 56/57, 2009/2010, s. 175.

35 T. Tomaszewski, Projekt ustawy o czynnościach operacyjno-rozpoznawczych analiza krytyczna, [w:] Co nowego w kryminalistyce — przeglad zagadnień z zakresu zwalczania przestępczości, red. E. Gruza, M. Goc, T. Tomaszewski, Warszawa 2010, s. 351.

${ }^{36}$ Zob. Z. Rau, Problematyka czynności operacyjno-rozpoznawczych $w$ świetle przeprowadzonych badań. Dziesięć lat prac nad ustawa - legislacyjna rozwaga czy porażka?, [w:] Przestępczość w XXI wieku - zapobieganie i zwalczanie. Problemy prawno-kryminologiczne, red. E. Pływaczewski, W. Filipkowski, Z. Rau, Warszawa 2015, s. 428.

Nowa Kodyfikacja Prawa Karnego 51, 2019

(C) for this edition by CNS 
pełnienia przestępstwa szpiegostwa lub przestępstwa o charakterze terrorystycznym oraz ujawniono jego sprawcę, a jest to uzasadnione względami bezpieczeństwa państwa bądź innymi względami istotnymi z punktu widzenia interesu państwa, kierownik właściwej służby państwowej może odstąpić od zawiadomienia właściwego prokuratora.

2. Kierownik właściwej służby państwowej, z zastrzeżeniem ust. 4 i 5, podejmuje decyzję, o której mowa w ust. 1, w przypadku gdy sprawca przestępstwa:

1) ujawnił wszelkie okoliczności popełnionego czynu;

2) zobowiązała się do podjęcia niejawnej współpracy z właściwą służbą państwową.

3. Przepisu ust. 1 nie stosuje się w przypadku gdy sprawca przestępstwa:

1) popełnił zbrodnię przeciwko życiu lub inne przestępstwo umyślne, którego skutkiem jest śmierć człowieka, ciężki uszczerbek na zdrowiu albo współdziałał w popełnieniu takiego przestępstwa lub usiłował je popełnić; albo

2) nakłaniał inną osobę do popełnienia czynu zabronionego, o którym mowa w pkt 1.

4. W przypadku gdy sprawca przestępstwa, nie podjął lub pomimo podjęcia niejawnej współpracy ze służbą państwową popełnił jedno z przestępstw, o którym mowa w ust. 3, lub podejmie współdziałanie w popełnieniu takiego przestępstwa albo będzie nakłaniał do jego popełnienia, kierownik służby państwowej powiadamia właściwego prokuratora.

5. Kierownik służby państwowej powiadamia właściwego prokuratora także w przypadku, gdy zostanie ujawnione, że sprawca przestępstwa, który podjął niejawną współpracę, umyślnie nie ujawnił wszelkich okoliczności czynu, o którym mowa w ust. 1, albo działa nadal na szkodę Rzeczypospolitej Polskiej.

Analiza tej propozycji pozwala na wyprowadzenie wniosku o jej dużej zbieżności z rozwiązaniami zawartymi w art. 22b ustawy o ABW i AW oraz art. 27a ustawy o SKW i SWW. Wśród różnic należy wskazać na ograniczenie kręgu podmiotów uprawnionych do ich stosowania tylko do służb kontrwywiadowczych, a więc ABW i SKW, co z uwagi na zakres zadań, które realizują jest rozwiązaniem trafnym. Ponadto odmiennie ujęto przesłanki, które uzasadniają takie decyzje szefów ABW lub SKW. W projekcie eksperckim u.o.c.o.r ujęto je bardzo ogólnie, wskazując, że do odstąpienia od zawiadomienia właściwego prokuratora może dojść wówczas, gdy jest to uzasadnione względami bezpieczeństwa państwa bądź innymi względami istotnymi z punktu widzenia interesu państwa. Wydaje się, że mamy w tym przypadku do czynienia ze zbyt szerokim pojęciem, które może zawierać bardzo zróżnicowany katalog interesów. Warto dodać, że w obowiązujących przepisach zawężono przesłanki, jakimi należy się kierować podczas podejmowania takich decyzji, wskazując tylko na względy bezpieczeństwa państwa. 
Zasadnicze wątpliwości wywołuje jednak kwestia kompetencji do decydowania o powiadomieniu prokuratora o popełnionym czynie. Zdecydowanej krytyce należy poddać rozwiązanie zaproponowane w art. 12 eksperckiego projektu u.o.c.o.r, w którym decyzję o rezygnacji ze ścigania karnego pozostawiono w gestii kierownika właściwej służby państwowej. Jak słusznie wskazuje R. Netczuk, przy tak dużym stopniu niedookreśloności przesłanek mogłoby to prowadzić do jej nadużywania ${ }^{37}$. $\mathrm{W}$ pełni uzasadnione byłoby natomiast poddanie takiej decyzji kontroli zewnętrznej, najlepiej prokuratorskiej. W art. 22b ust. 3 ustawy o ABW i AW oraz art. 27a ust. 3 ustawy o SKW i SWW wskazuje się, że szefowie ABW i SKW mogą odstąpić od obowiązku zawiadomienia właściwego prokuratora po zasięgnięciu opinii Prokuratora Generalnego oraz ministra - członka Rady Ministrów właściwego do spraw koordynowania działalności służb specjalnych, jeżeli został powołany. Rozwiązanie to trudno uznać za w pełni satysfakcjonujące, gdyż w tych przepisach wskazano na konieczność zasięgnięcia opinii, nie zaś uzyskania zgody Prokuratora Generalnego. W praktyce trudno sobie wyobrazić podjęcie decyzji o odstąpieniu od zawiadomienia właściwego prokuratora przez Szefa ABW lub SKW pomimo negatywnej opinii Prokuratora Generalnego. Niemniej w tym względzie ostateczną decyzję przepisy pozostawiają w rękach kierowników uprawnionych do tego służb. Z uwagi na istotność spraw, w których takie rozstrzygnięcia mogą zapadać, należałoby postulować taką zmianę przepisów, by dopiero formalna zgoda Prokuratora Generalnego, uzyskana przez szefów wymienionych służb, pozwalała na uruchomienie procedury pozyskiwania TW.

Warto też zasygnalizować kwestie, które w sposób wysoce niedoskonały próbowano uregulować w eksperckim projekcie u.o.c.o.r., a nie zostały podjęte $\mathrm{w}$ art. $22 \mathrm{~b}$ ustawy o ABW i AW oraz art. 27a ustawy o SKW i SWW. Przede wszystkim dotyczy to charakteru prawnego stosunków łączących TW z jedną ze służb kontrwywiadowczych, czyli zobowiązania się do tajnej współpracy ${ }^{38}$. Nie określono w żaden sposób, co należałoby rozumieć przez wywiązanie przez TW z podjętych zobo-

37 R. Netczuk, Tajny wspótpracownik i tajny agent $w$ projektach ustaw o czynnościach o czynnościach operacyjno-rozpoznawczych: uwagi de lege ferenda, „Wojskowy Przegląd Prawniczy" 2010, nr 3, s. 18.

38 Zob. szerzej P. Herbowski, op. cit., s. 157-160.

Nowa Kodyfikacja Prawa Karnego 51, 2019

(C) for this edition by CNS 
wiązań. Biorąc pod uwagę specyfikę działania takich służb, potencjalny kandydat na TW może mieć zasadnicze wątpliwości, czy racjonalne i zgodne z jego interesem będzie podjęcie współpracy, jeśli decyzja o jej zakończeniu leży całkowicie w gestii danej służby oraz jej Szefa i nie podlega żadnej kontroli, na przykład prokuratorskiej. Należałoby rozważyć możliwość wprowadzenia takiej kontroli, gdyż mogłoby to stanowić pewnego rodzaju zabezpieczenie przed zmuszaniem TW do dalszej współpracy poza zakresem określonym w zobowiązaniu. Obecnie wydaje się, że brak faktycznej kontroli prokuratorskiej nad pozyskaniem TW przez służby kontrwywiadowcze na podstawie materiałów obciążających może stanowić największą przeszkodę w podejmowaniu takiej współpracy, z uwagi na przedstawione zasadne obawy kandydatów na TW. Trzeba też dodać, że zarówno w ustawie o ABW i AW, jak i ustawie o SKW i SWW nie podjęto tak istotnych kwestii jak posiadanie lub dostarczenie przez TW funkcjonariuszowi operacyjnemu przedmiotów pochodzących z przestępstwa, ulegających przepadkowi albo których wytwarzanie, posiadanie, przewożenie lub którymi obrót są zabronione. W praktyce najczęściej będą to narkotyki, fałszywe banknoty, broń lub materiały wybuchowe. Inaczej rzecz ujmując, to wszelkiego rodzaju przedmioty uzyskane w trakcie działań operacyjnych w warunkach, które nie spełniają wymogów określonych w ustawach kompetencyjnych służb specjalnych regulujących zakup kontrolowany, kontrolowane przyjęcie lub wręczenie korzyści majątkowej czy też przesyłkę niejawnie nadzorowaną. Przedmioty te mogą być także w procesie karnym źródłem informacji jako dowody rzeczowe. Całkowicie pominięto też kwestię ewentualnego udziału TW w popełnianiu przestępstw, które nie będą miały charakteru szpiegowskiego ani terrorystycznego, a w których może być on zmuszony uczestniczyć, by inne osoby nie nabrały podejrzeń co do jego ewentualnej współpracy z ABW lub SKW. Nie odniesiono się też do ewentualnej możliwości uchylenia tymczasowego aresztowania kandydata na TW, jak też pomocy w uzyskaniu przez niego odroczenia lub przerwy w odbywaniu kary. W obliczu podniesionych wątpliwości istnieją też podstawy do tego, by postulować udział w kontroli działań polegających na pozyskaniu i współpracy z TW prokuratorów z Departamentu do Spraw Przestępczości Zorganizowanej i Korupcji Prokuratury Krajowej. Byłoby to uzasadnione zwiększeniem trafności ocen uzyskanej wiedzy 
operacyjnej, której przydatność $\mathrm{w}$ toku prowadzonych czynności wykrywczych, ale także dowodowych, z punktu widzenia interesu wymiaru sprawiedliwości, ma znacznie przewyższające szkodliwość czynu lub czynów, z których ścigania się zrezygnuje. Pozwalałoby to również ukierunkować czynności operacyjno-rozpoznawcze, w których planowany jest udział TW, w taki sposób, by poza zdobywaniem wiedzy operacyjnej pozyskiwać również informacje o dowodach możliwych do wykorzystania i przeprowadzenia $\mathrm{w}$ sądzie $^{39}$. Wymagałoby to jednak wielu zmian w przepisach regulujących korzystanie z tego instrumentu prawnego.

\section{Wykorzystanie informacji od tajnego współpracownika}

Udzielenie odpowiedzi na pytanie dotyczące sposobów wykorzystania informacji przekazanych przez TW nie jest sprawa łatwą, gdyż czynności operacyjno-rozpoznawcze służb specjalnych o charakterze kontrwywiadowczym nie służą, jak to ma miejsce w przypadku służb policyjnych, wyłącznie ściganiu karnemu.

Zasadniczych różnic $\mathrm{w}$ odniesieniu do celów, którym ma służyć współpraca z TW, należy upatrywać w funkcjach czynności operacyjnych. A. Taracha wskazuje, że czynności te pełnią funkcje informacyjną, wykrywczą, profilaktyczną i dowodową ${ }^{40}$. W przypadku podjęcia współpracy z TW, gdy jego dotychczasowa aktywność miała charakter szpiegowski, na pierwszy plan wysuwa się funkcja informacyjna, która jest realizowana głównie przez służby specjalne ${ }^{41}$. Funkcja ta jest wprost wymieniana ${ }^{42} \mathrm{w}$ art. 5 ust. 1 pkt 4 ustawy o ABW i AW, gdyż do podstawowych zadań ABW należy uzyskiwanie, analizowanie, przetwarzanie i przekazywanie właściwym organom informacji mogących mieć istotne znaczenie dla ochrony bezpieczeństwa wewnętrznego państwa i jego po-

39 Zob. E. Pływaczewski, Kilka uwag do projektu ustawy o Prokuraturze RP, [w:] Zasady procesu karnego wobec wyzwań wspótczesności. Ksiega ku czci Profesora Stanistawa Waltosia, red. J. Czapska et al., Warszawa 2000, s. 137.

40 A. Taracha, Czynności operacyjno-rozpoznawcze. Aspekty kryminalistyczne i prawnodowodowe, Lublin 2006, s. 25.

${ }^{41}$ M. Bożek et al., Stużby specjalne w strukturze władz publicznych. Zagadnienia prawnoustrojowe, Warszawa 2014, s. 114.

42 A. Taracha, Czynności operacyjno-rozpoznawcze..., s. 27-28.

Nowa Kodyfikacja Prawa Karnego 51, 2019

(C) for this edition by CNS 
rządku konstytucyjnego. W podobny sposób zadanie to sformułowano w odniesieniu do SKW w art. 5 ust. 1 pkt 4 ustawy o SKW i SWW.

Odmiennie natomiast przedstawia się kwestia funkcji realizowanych w trakcie współpracy z TW, prowadzącym działalność zmierzającą do popełnienia przestępstw o charakterze terrorystycznym. Wydaje się, że w tym przypadku realizacja funkcji informacyjnej schodzi na dalszy plan, a pierwszoplanowa wydaje się funkcja zapobiegawcza, określana także mianem profilaktycznej. Taki wybór jest w pełni uzasadniony, jeśli przyjmiemy, że obejmuje ona również działania dezintegrujące i dezinformujące. Będzie to miało miejsce nie tylko wtedy, gdy wyprzedzające informacje od TW pozwolą na bezpośrednie zapobiegnięcie planowanemu przestępstwu o charakterze terrorystycznym. Z o wiele wyższym stopniem zaawansowania takich działań mamy bowiem do czynienia w przypadku dezintegracji i dezinformacji grup terrorystycznych, przez co należy rozumieć ,rozprzężenie, rozbicie i wzajemne zantagonizowanie sił przeciwnika i ich rozsadzenie od wewnątrz bądź przez dezinformacyjne stymulowanie posunięć i zachowań przeciwnika w pożądanym przez nas kierunku"43. T. Hanausek uważał nawet, że działania te są wręcz odrębną funkcją czynności operacyjnych, przy okazji przyznając jednak, że służą one głównie celom profilaktycznym ${ }^{44}$. Bez wątpienia funkcję tę w największym stopniu, spośród wszystkich form pracy operacyjnej, będą urzeczywistniały czynności podejmowane przez źródła osobowe uplasowane w inwigilowanych środowiskach. Będą one związane zarówno z dostarczaniem przez TW informacji, jak i przede wszystkim z ich aktywną działalnością dezinformacyjną i dezintegrującą oraz realizowaniem skomplikowanych zadań operacyjnych zlecanych przez prowadzących ich funkcjonariuszy.

Współpraca służb kontrwywiadowczych z TW będzie też w pewnym stopniu służyła również realizacji funkcji wykrywczej i dowodowej. Nie ulega bowiem wątpliwości, że analizowana instytucja jest jednym z kluczowych elementów wprowadzonych ustawą o działaniach antyterrorystycznych i nie może być oceniana w oderwaniu od innych przepisów tej regulacji. W szczególności dotyczy to możliwości wykorzystania informacji uzyskanych od TW na podstawie art. 26 ustawy o działaniach antyterrory-

43 T. Hanausek, Kryminalistyka a praca operacyjna, „Problemy Kryminalistyki” 1988, nr 182, s. 446.

44 Ibidem, s. 447.

Nowa Kodyfikacja Prawa Karnego 51, 2019

(C) for this edition by CNS 
stycznych, który zdaniem M. Gabriela-Węglowskiego jest najbardziej kontrowersyjnym uregulowaniem całej ustawy ${ }^{45}$. Przepis ten daje możliwość przedstawienia zarzutów karnych dotyczących przestępstwa o charakterze terrorystycznym na podstawie informacji uzyskanych w wyniku czynności operacyjno-rozpoznawczych, jeżeli wymaga tego dobro postępowania karnego. Wskazano w nim też samoistną przesłankę do zastosowania tymczasowego aresztowania przez sąd na podstawie wniosku prokuratora, a jest nią uprawdopodobnienie popełnienia, usiłowania lub przygotowania do popełnienia przestępstwa o charakterze terrorystycznym.

Trzeba podzielić wiele zastrzeżeń wysuniętych przez T. Gardocką wobec analizowanego przepisu ${ }^{46}$. W ustawie antyterrorystycznej ustawodawca nie wskazał także, czy ustalenia można opierać na każdej nieprocesowej, lecz mieszczącej się w kompetencjach ustawowych czynności uprawnionych organów ${ }^{47}$. Nie sposób zatem określić, jak na przykład w świetle tych przepisów należałoby potraktować meldunki informacyjne sporządzane na postawie informacji pochodzących od TW. Stanowią one niejednokrotnie bardzo istotną część zebranych materiałów operacyjnych. Powstają też wątpliwości, czy wniosek o zastosowanie tymczasowego aresztowania może zostać oparty przez prokuratora tylko na wyselekcjonowanych materiałach operacyjnych. Zasadne byłoby danie sądowi możliwości zapoznania się z całością zebranych materiałów, a we wniosku szczegółowe określenie, które z nich uznano za wiarygodne i uzasadniające podejrzenie popełnienia przestępstwa o charakterze terrorystycznym, a które nie zasługują na danie im wiary i dlaczego. Takie postępowanie byłoby racjonalne, biorąc pod uwagę praktykę prowadzenia czynności operacyjnych, w trakcie których wiele działań jest ukierunkowanych na poszukiwanie nawet szczątkowych informacji o osobach czy też środowiskach zajmujących się działalnością niezgodną z prawem. Wybiórcze prezentowanie materiałów operacyjnych nie dawałoby sądowi szansy na ich własną ocenę, na przykład gdyby zachodziła sprzeczność między infor-

45 M. Gabriel-Węglowski, Działania antyterrorystyczne. Komentarz, Lex 2018, komentarz do art. 26, https://sip.lex.pl/\#/commentary/587754141/551581/gabriel-weglowskimichal-dzialania-antyterrorystyczne-komentarz?cm=SREST (dostęp: 4.06.2019).

46 Zob. T. Gardocka, Ustawa antyterrorystyczna a wolności konstytucyjne, [w:] Pozyskiwanie informacji $w$ walce..., s. 86-87.

47 M. Gabriel-Węglowski, op. cit.

Nowa Kodyfikacja Prawa Karnego 51, 2019

(C) for this edition by CNS 
macjami pochodzącymi od TW a tymi uzyskanymi na przykład w wyniku stosowania kontroli operacyjnej. Wbrew twierdzeniom pojawiającym się w piśmiennictwie, tym ostatnim nie zawsze można przypisywać waloru wiarygodności. Należy raczej zakładać możliwość stosowania działań kontrwykrywczych, ukierunkowanych na ograniczenie skuteczności kontroli operacyjnej ${ }^{48}$, przez osoby prowadzące działalność zarówno terrorystyczną, jak i szpiegowską. Trzeba więc odrzucić pogląd M. Gabriela-Węglowskiego, kwestionującego możliwość przekonania sądu o wysokim prawdopodobieństwie popełnienia przestępstwa na podstawie informacji uzyskanych od $\mathrm{TW}^{49}$, gdyż takiego ich wykorzystania nie można z założenia wykluczać.

Kolejną kwestią jest wprowadzenie do materiałów postępowania karnego nagrania zarejestrowanego przez TW na przykład podczas spotkania, w którego trakcie planowano przeprowadzenie zamachów terrorystycznych lub działań o charakterze szpiegowskim. Pomimo pozaprocesowego sposobu uzyskania takiego nagrania nie można powiedzieć, że mamy do czynienia z uzyskaniem substratu środka dowodowego ${ }^{50}$. Takie nagranie może mieć bowiem bardzo duże znaczenie dowodowe, zbliżone do wartości dowodu uzyskanego w trakcie kontroli operacyjnej. Jego wartość może także wzmocnić opinia biegłego z zakresu badań fonoskopijnych. Biorąc pod uwagę bardzo duży stopień społecznej szkodliwości przestępstw o charakterze terrorystycznym oraz szpiegowskim, nie można wykluczyć takiej ewentualności. Odrzucanie możliwości wykorzystania w procedurze określonej w art. 26 ustawy antyterrorystycznej informacji operacyjnych uzyskanych od TW byłoby też sprzeczne z trafnym stanowiskiem zaprezentowanym przez Sąd Najwyższy, że ,[...] w k.p.k. nie sformułowano zamkniętego katalogu dowodów, w związku z czym dowodem może być wszystko to, co przyczynić się może do wyjaśnienia sprawy" ${ }^{\prime \prime}$. Wydaje się, że art. 26 ustawy antyterrorystycznej skłania też

48 Zob. szerzej P. Łabuz, T. Safjański, Działania kontrwykrywcze grup przestępczych ukierunkowane na ograniczenie skuteczności kontroli operacyjnej oraz procesowej kontroli i utrwalania rozmów, „Problemy Kryminalistyki” 2017, nr 297, s. 28-34.

${ }^{49}$ M. Gabriel-Węglowski, op. cit.

50 Zob. ibidem.

51 Postanowienie SN z 7 marca 2001 r., IV KKN 488/00, LEX nr 51100.

Nowa Kodyfikacja Prawa Karnego 51, 2019

(C) for this edition by CNS 
do zastanowienia się, czy nie mamy do czynienia z jedną z niewielu sytuacji, gdy dla wzmocnienia posiadanego materiału dowodowego warto byłoby przesłuchać TW jako świadka utajnionego.

\section{Podsumowanie}

Wprowadzenie przepisów prawnych umożliwiających pozyskanie TW przez służby kontrwywiadowcze na podstawie materiałów obciążających było następstwem uzasadnionego przekonania, że posiadane przez nie uprawnienia nie są wystarczające do skutecznego zwalczania licznych zagrożeń dla bezpieczeństwa państwa o charakterze terrorystycznym, jak też infiltracji przez obce służby wywiadowcze. Jednak w przypadku zaistnienia konfliktu pomiędzy chronionymi konstytucyjnie dobrami takimi jak prawo do prywatności, tajemnica porozumiewania się oraz ochrona autonomii informacyjnej a względami bezpieczeństwa publicznego konieczne jest zachowanie przez ustawodawcę czytelnej równowagi między interesami pozostającymi $\mathrm{w}$ kolizji ${ }^{52}$. Z takim też konfliktem mamy niejednokrotnie do czynienia w wypadku wielu form pracy operacyjnej, jednak nie w przypadku TW. Nie zmienia to faktu, że kwestie o istotnym znaczeniu dla urzeczywistnienia praw i wolności obywateli powinny być w sposób zupełny i wyczerpujący uregulowane $\mathrm{w}$ akcie prawnym rangi ustawy. Tymczasem istnieje wiele wątpliwości, podniesionych w niniejszym opracowaniu, czy tak się stało. Analizowany instrument prawny był z pewnością długo wyczekiwany przez polskie służby kontrwywiadowcze i w swoich założeniach niewątpliwie służy podniesieniu poziomu bezpieczeństwa państwa i jego obywateli. Jednak przepisy ustawowe nie rozstrzygają wielu kwestii, które stawiają realność takiej współpracy pod dużym znakiem zapytania, co może skutkować tym, że rozwiązanie to może nie być stosowane w praktyce.

52 Uzasadnienie do wyroku TK z 23 czerwca 2009 r. w sprawie K 54/07, OTK ZU 2009, nr 6A, poz. 86 . 


\section{Bibliografia}

Babiński A., Ustawa antyterrorystyczna - legislacja na rzecz bezpieczeństwa, [w:] Polska ustawa antyterrorystyczna: odpowiedź na zagrożenia współczesnym terroryzmem, red. W. Zubrzycki, K. Jałoszyński, A. Babiński, Szczytno 2016.

Bożek M., Czuryk M., Karpiuk M., Kostrubiec J., Stużby specjalne w strukturze władz publicznych. Zagadnienia prawnoustrojowe, Warszawa 2014.

Gabriel-Węglowski M., Działania antyterrorystyczne. Komentarz, Lex 2018, komentarz do art. 26, https://sip.lex.pl/\#/commentary/587754141/551581/gabriel-weglowskimichal-dzialania-antyterrorystyczne-komentarz?cm=SREST (dostęp: 4.06.2019).

Gardocka T., Ustawa antyterrorystyczna a wolności konstytucyjne, [w:] Pozyskiwanie informacji $w$ walce z terroryzmem, Warszawa 2017.

Hanausek T., Kryminalistyka a praca operacyjna, „Problemy Kryminalistyki” 1988, nr 182. Herbowski P., Poufne osobowe źródła informacji. Aspekty kryminalistyczne i prawnodowodowe, Warszawa 2018.

Hoc S., O tak zwanym szpiegu i terroryście koronnym, „Nowa Kodyfikacja Prawa Karnego" 43, 2017.

Jagiełło R., Wybrane aspekty wojskowego rozpoznania osobowego, „Przegląd Bezpieczeństwa Wewnętrznego" 2013, nr 5.

Konieczny J., Kryzys czy zmiana paradygmatu kryminalistyki?, „Państwo i Prawo” 2012, z. 1.

Kostrzewa-Zorbas G., Zachwycone technologia i prawem, stużby specjalne USA nie rozumieja ludzi i kultur. Błąd stary, ale żywy i zaraźliwy, http://wpolityce.pl/swiat/296394-zachwycone-technologia-i-prawem-sluzby-specjalne-usa-nie-rozumiejaludzi-i-kultur-blad-stary-ale-zywy-i-zarazliwy (dostęp: 17.05.2019).

Kulicki M., Kwiatkowska-Darul V., Stępka L., Kryminalistyka. Wybrane zagadnienia teorii i praktyki śledczo-sądowej, Toruń 2005.

Kurzępa B., Podstęp w toku czynności karnoprocesowych i operacyjnych, Toruń 2003.

Lubiewski P., Ustawa antyterrorystyczna wobec stużb specjalnych. Rozszerzenie czy aktualizacja, [w:] Polska ustawa antyterrorystyczna: odpowiedź na zagrożenia wspólczesnym terroryzmem, Szczytno 2016.

Łabuz P., Safjański T., Działania kontrwykrywcze grup przestepczych ukierunkowane na ograniczenie skuteczności kontroli operacyjnej oraz procesowej kontroli i utrwalania rozmów, „Problemy Kryminalistyki” 2017, nr 297.

Mąka J., Ustawa o czynnościach operacyjno-rozpoznawczych - czy jest potrzebna w obecnym stanie prawnym w Polsce?, „Prokuratura i Prawo” 2009, nr 4.

Musiał F., Podręcznik bezpieki. Teoria pracy operacyjnej Stużby Bezpieczeństwa w świetle wydawnictw resortowych Ministerstwa Spraw Wewnętrznych PRL (1970-1989), Kraków 2007.

Netczuk R., Tajny wspótpracownik i tajny agent w projektach ustaw o czynnościach o czynnościach operacyjno-rozpoznawczych: uwagi de lege ferenda, „Wojskowy Przegląd Prawniczy" 2010, nr 3.

Nowikowski I., Bezpieczeństwo państwa a prawa oskarżonego w polskim prawie karnym procesowym (kwestie wybrane), Teka Komisji Prawniczej O.L. PAN, 2018, t. 11, nr 2. 
Olejnik K., Zakres stosowania czynności operacyjnych — stan faktyczny, oczekiwania, potrzeby i możliwości wykorzystania ustaleń operacyjnych $w$ procesie karnym oraz dopuszczalny udziat sędziego i prokuratora $w$ działaniach operacyjnych, [w:] Praktyczne elementy zwalczania przestępczości zorganizowanej i terroryzmu. Nowoczesne technologie i praca operacyjna, red. L. Paprzycki, Z. Rau, Warszawa 2009. Olsztyn W., Nowe rozwiąania w obszarze działań operacyjno-rozpoznawczych oraz procesowych wynikajace z ustawy o działaniach antyterrorystycznych, [w:] Polska ustawa antyterrorystyczna: odpowiedź na zagrożenia współczesnym terroryzmem, Szczytno 2016.

Pływaczewski E., Kilka uwag do projektu ustawy o Prokuraturze RP, [w:] Zasady procesu karnego wobec wyzwań współczesności. Ksiega ku czci Profesora Stanisława Waltosia, red. J. Czapska, A. Gaberle, A. Światłowski, A. Zoll, Warszawa 2000.

Rau Z., Czynności operacyjno-rozpoznawcze w polskim systemie prawa - działania $w$ kierunku uniwersalnej ustawy, [w:] Praktyczne elementy zwalczania przestępczości zorganizowanej i terroryzmu. Nowoczesne technologie i praca operacyjna, Warszawa 2009.

Rau Z., Problematyka czynności operacyjno-rozpoznawczych $w$ świetle przeprowadzonych badań. Dziesięć lat prac nad ustawa - legislacyjna rozwaga czy porażka?, [w:] Przestępczość w XXI wieku - zapobieganie i zwalczanie. Problemy prawno-kryminologiczne, red. E. Pływaczewski, W. Filipkowski, Z. Rau, Warszawa 2015.

Rudniański J., Elementy prakseologicznej teorii walki. Z zagadnień kooperacji negatywnej, Warszawa 1983.

Staszak A., Porwania w celu wymuszenia okupu. Studium kryminalistyczne, Opole 2010. Szuniewicz-Stępień M., Działania operacyjno-rozpoznawcze w ustawie antyterrorystycznej a europejski standard ochrony praw człowieka - wybrane zagadnienia, [w:] Polska ustawa antyterrorystyczna: odpowiedź na zagrożenia współczesnym terroryzmem, Szczytno 2016.

Taracha A., Czynności operacyjno-rozpoznawcze. Aspekty kryminalistyczne i prawnodowodowe, Lublin 2006.

Taracha A., Glosa do wyroku Trybunatu Konstytucyjnego z dnia 20 kwietnia 2004 r. (sygn. akt K 45/02), „Przegląd Sejmowy” 2004, nr 6.

Taracha A., Nowe regulacje dotyczace czynności operacyjno-rozpoznawczych zawarte $w$ Ustawie z dnia 10 czerwca 2016 r. o działaniach antyterrorystycznych, [w:] Pozyskiwanie informacji $w$ walce z terroryzmem, red. P. Herbowski, D. Słapczyńska, D. Jagiełło, Difin, Warszawa 2017.

Taracha A., O „Projekcie ustawy o czynnościach operacyjno-rozpoznawczych”, „Annales Universitatis Mariae Curie-Skłodowska. Sectio G” 56/57, 2009/2010.

Taracha A., Uzyskiwanie $i$ wykorzystywanie dla celów bezpieczeństwa informacji o osobie a prawa jednostki (zagadnienia wybrane), Teka Komisji Prawniczej O.L. PAN, 11, 2018, nr 2. Taracha A., Z problematyki sporzadzania $i$ wydawania operacyjnych dokumentów legalizacyjnych, [w:] Dokument i jego badania, red. R. Cieśla, Wroclaw 2014.

Tomaszewski T., Projekt ustawy o czynnościach operacyjno-rozpoznawczych - analiza krytyczna, [w:] Co nowego w kryminalistyce - przegląd zagadnień z zakresu zwalczania przestępczości, red. E. Gruza, M. Goc, T. Tomaszewski, Warszawa 2010. 
Wosek M., Działania antyterrorystyczne w aspekcie praw czlowieka $i$ wolności obywatelskich, [w:] Polska ustawa antyterrorystyczna: odpowiedź na zagrożenia wspótczesnym terroryzmem, Szczytno 2016.

Zalewski S., Czynności operacyjno-rozpoznawcze jako forma realizacji zadań stużb specjalnych w systemie bezpieczeństwa państwa, „Przegląd Policyjny” 2002, nr 3-4. Zubrzycki W., Dzieje ustawy antyterrorystycznej w Polsce, [w:] Polska ustawa antyterrorystyczna: odpowiedź na zagrożenia wspótczesnym terroryzmem, Szczytno 2016.

\section{Recruiting a secret collaborator by counterintelligence services based on incriminating materials - considerations on the sense of the institution}

\section{Summary}

The basic task of state authority is to ensure the security of state structures and its citizens. This can be achieved by legal solutions allowing the counterintelligence services to recruit secret collaborators based on possessed incriminating materials. This instrument meets the expectations of Polish counterintelligence services, however, the lack of resolution of many issues puts into question the possibility of its application in practice.

Keywords: secret collaborator, incriminating materials, counterintelligence services, state security. 